\title{
Do Water Matrix and Particulate Buffering Capacity Affect the Rate and Extent of P Release?
}

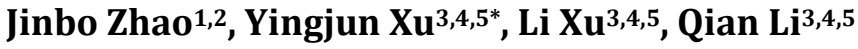 \\ ${ }^{1}$ State Key Laboratory of Water Environment Simulation, School of Environment, Beijing Normal University, \\ Beijing, China \\ ${ }^{2}$ University of Plymouth, School of Geography, Earth and Environmental Sciences, Plymouth, UK \\ ${ }^{3}$ Faculty of Geographical Science, Beijing Normal University, Beijing, China \\ ${ }^{4}$ State Key Laboratory of Earth Surface Processes and Resource Ecology, Beijing Normal University, Beijing, China \\ ${ }^{5}$ Key Laboratory of Environmental Change and Natural Disaster, Ministry of Education of China, Beijing Normal University, \\ Beijing, China \\ Email: ${ }^{\star} x y j @ b n u . e d u . c n$
}

How to cite this paper: Zhao, J.B., Xu, Y.J., $\mathrm{Xu}, \mathrm{L}$. and Li, Q. (2018) Do Water Matrix and Particulate Buffering Capacity Affect the Rate and Extent of P Release? Journal of Water Resource and Protection, 10, 59-72. https://doi.org/10.4236/jwarp.2018.101004

Received: December 7, 2017

Accepted: January 26, 2018

Published: January 29, 2018

Copyright (c) 2018 by authors and Scientific Research Publishing Inc. This work is licensed under the Creative Commons Attribution International License (CC BY 4.0).

http://creativecommons.org/licenses/by/4.0/

\begin{abstract}
The aim of this study was to investigate the release of inorganic and organic phosphorus species from particles in rivers and estuaries during resuspension events such as storm, wind and tidal induced turbulence. To achieve this aim, laboratory beaker experiments were designed with autoanalyzer 3 (AA3). The study first investigates phosphorus equilibration in ultra-pure water (UHP) water, biotic river water and abiotic river water under short term and long term conditions. Then, three typical organic and inorganic phosphorus compounds were selected (orthophosphate, phytic acid (PTA) and $\beta$-D-glucose-6phosphate monosodium salt (G-6-P)) to simulate the effect of addition input to river and estuaries in the time period of $150 \mathrm{~h}$. The results show that in a turbulent river, dissolved inorganic phosphorus (DIP) and dissolved organic phosphorus (DOP) will reach equilibrium between the particulate matter and the water column within $24 \mathrm{~h}$. Additional input of DIP or DOP to the river, has different effects to the river nutrients balance. The buffering capacity of the suspended particulate matter (SPM) plays an important role and behavior difference to the inorganic and various organic phosphorus compounds.
\end{abstract}

\section{Keywords}

Nonpoint Source Pollution, Phosphorus, Resuspension, Particulate Matter, Laboratory Beacker Experiment, River

\section{Introduction}

High winds, storms and tidal change in estuaries increase shear stress on the 
benthic sediment, resulting in increased SPM concentrations and transport of particulate material to coastal waters [1] [2]. SPM has a large exposed surface area compared with benthic sediment, with easier access to dissolved oxygen, organic matter, macronutrients and micronutrients, facilitating the attachment and growth of bacteria [3] [4]. Therefore resuspension of particulate matter can give rise to chemical and biological changes in the water column.

The release/uptake P mechanisms between SPM and water has been studied in recent years. The key factors are temperature [5] [6] [7] $\mathrm{pH}$ [8] [9], dissolved oxygen [10], redox conditions (Eh) [11] [12], microbes [13] [14], SPM size distribution [15] [16] and SPM texture [17], the organic matter content of the sediment and salinity [18].

Normally, under natural conditions, the phosphorus concentrations (including organic and inorganic phosphorus) should have a balance between adsorption and desorption processes of SPM. The complexity of SPM composition has the capability to allow $\mathrm{P}$ concentration to be constant to a certain level in the aqueous solution to a certain time. The property of SPM to resist fast uptake or release $\mathrm{P}$ to the aqueous solution is called buffer capacity. If the SPM has buffer capacity to P compounds, it means that the SPM could control the P transfer and possess at a certain time, in addition to reduce/slow down negative effects of $P$ contaminants on the water quality.

This paper is a cross-disciplinary study which is providing the effects of exogenous nutrient input such as organic and inorganic phosphorus fluxes on water quality. To achieve this, we focused on SPM on the effects of "alive" or "dead", "short term" or "long term" resuspension, response to the "labile" or "refractory" organic phosphorus and "ideal" or river or sea water matrices. The specific objectives were to: determine $\mathrm{P}$ speciation in the autoclaved and non-autoclaved SPM; investigate phosphorus equilibration in UHP water, biotic river water and autoclaved river water over short $(5 \mathrm{~h}$ ) and long (3 day) time scales; quantify DIP (orthophosphate) and DOP (G-6-P and phytic acid) exchange between SPM and the water column at a fixed shear stress in spiked UHP water, biotic river water and autoclaved river water over short $(20 \mathrm{~h})$ and long (5 day) time scales; study the effects of the water matrix and bacteria on phosphorus exchange.

\section{Experimental}

\subsection{Sampling}

The suspended particulate matter and water were collected from the Tamar Estuary which is a typical, turbid macrotidal estuary for which extensive background water quality data are available [19]-[25]. The Tamar Estuary drains an area of $590 \mathrm{~km}^{2}$. The length of the estuary, from Gunnislake (the tidal limit) to the mouth of the estuary in Plymouth Sound is $31.5 \mathrm{~km}$. The geology of the region is mainly composed of underlying slate, limestone and grit. Estuarine flushing time is typically one day in winter [26], when instantaneous flow can 
exceed $38 \mathrm{~m}^{3} \cdot \mathrm{s}^{-1}$, increasing to one week in summer when flows can be as low as $5 \mathrm{~m}^{3} \cdot \mathrm{s}^{-1}$. A sedimentation basin particle sampler (SBPS), supplied by Dr Matthias Ricking from the Free University of Berlin, was used to collect resuspended particles (kg amounts) for characterization and experimentation. Before deployment the SBPS sampler was soaked in $0.5 \% \mathrm{~m} / \mathrm{v}$ detergent (Nutricon), rinsed thoroughly with ultra high purity (UHP) water and air dried. The SBPS was deployed with the inlets facing upstream at a depth of $\sim 1 \mathrm{~m}$ at a riverine sampling station near Gunnislake (SX 426 725) for 2 - 4 week periods during the winter. Samples were then transferred from the SBPS into high density polyethylene (HDPE) bottles using an acid washed plastic scoop. The sample slurries were then frozen at $-20^{\circ} \mathrm{C}$ until use. The sedimentation basin system consisted of a sedimentation unit and a filtration unit. River water was routed into the sedimentation basin via inlet holes and slowed down by the blades and SPM was deposited in the sedimentation basin by gravitational settling.

\subsection{Water Matrices and Sterilisation of SPM and River Water}

1) UHP water $\left(\geq 18.2 \mathrm{M} \Omega \cdot \mathrm{cm}^{-1}\right)$. This was used to simulate phosphorus release from suspended sediment to a theoretically pristine river water (salinity $=0$, no phosphorus) at $\mathrm{pH} \sim 6$.

2) Gunnislake river water. This was used to determine phosphorus release from suspended sediment to a real river water $(\mathrm{S}=0)$ at $\mathrm{pH} \sim 7$.

3) Autoclaved Gunnislake river water. This was used to investigate phosphorus release from suspended sediment to a real river water under autoclaved conditions (Salinity $=0$ ) at $\mathrm{pH} \sim 7$. Ten $\mathrm{L}$ of filtered Gunnislake water was autoclaved for $30 \mathrm{~min}$ at $121^{\circ} \mathrm{C}$ and $15 \mathrm{lb}^{-2}$ pressure.

\subsection{Experimental Design}

Phosphorus equilibration and exchange experiments were set up in a laboratory environment to simulate Gunnislake SPM under water conditions. Previous paper had the details of the P model compounds selection [27]. Resuspension was achieved by stirring the solution with a magnetic stirrer at a fixed stirring rate (1200 rpm, to keep the particulate material in suspension). Gunnislake SPM and water separately autoclaved and then was mixed in a ratio of $4 \mathrm{~g}$ slurry to $1 \mathrm{~L}$ of water at ambient temperature $\left(10^{\circ} \mathrm{C}-22^{\circ} \mathrm{C}\right)$ in a well oxygenated environment $\left(\mathrm{O}_{2}\right.$ saturation $\left.>90 \%\right)$. Autoclaved experiments were carried out in a class 100 laminar flow cabinet (BassAIRE). To investigate natural DIP and DOP equilibration. The kinetics of $\mathrm{P}$ equilibration were investigated over short $(5 \mathrm{~h})$ and long (3 day) time scales. Autoclaved conditions were maintained in control experiments; to investigate DIP and DOP exchange in these continuously stirred, pre-equilibrated batch reactors, G-6-P (labile), phytic acid (refractory) and orthophosphate were separately spiked into the UHP and river water matrices to make sure the final concentrations are $80 \mu \mathrm{g} \mathrm{P} \mathrm{L}{ }^{-1}$. The concentration of $80 \mu \mathrm{g} P$ 
$\mathrm{L}^{-1}$ was chosen because it was at the upper end of the range of TDP concentrations typically found in the Gunnislake river water and because it provided analytically robust measurements. The kinetics of $\mathrm{P}$ exchange were investigated over short (15 h) and long (6 day) time scales.

\subsection{Sample Sequence}

Stage 1. The kinetics of $\mathrm{P}$ exchange was investigated over the short term $(5 \mathrm{~h})$ and long term (3 days).

1) The water matrix (1 L) was stirred, the $T_{0}$ sample was taken with a syringe, and then SPM slurry $\left(0.5 \mathrm{~g} \cdot \mathrm{L}^{-1}\right)$ was added.

2) From $T_{1}-T_{10}$ samples $(30 \mathrm{~mL})$ were taken every $30 \mathrm{~min}$.

3) Sample $T_{11}$ was taken after $24 \mathrm{~h}$.

4) Sample $T_{12}$ was taken after $48 \mathrm{~h}$.

5) Sample $T_{13}$ was taken after $72 \mathrm{~h}$.

Stage 2. The reactors were separately spiked with ortho-phosphate (potassium dihydrogen phosphate $\mathrm{KH}_{2} \mathrm{PO}_{4}$ ), G-6-P and phytic acid.

6) Sample $S_{1}$ was taken after each reactor had reached a steady state (defined by a change of $<5 \%$ in the $\mathrm{P}$ concentration in the water column between samples). Then each reactor was immediately spiked with $80 \mu \mathrm{g} \mathrm{P} \mathrm{L} \mathrm{L}^{-1}$ ortho-phosphate, G-6-P or phytic acid.

7) Samples $S_{2}, S_{3}, S_{4}$ and $S_{5}$ were taken every $4 \mathrm{~h}$ at $4,8,12$ and $16 \mathrm{~h}$ for the short-term investigation.

8) Sample $S_{6}$ was taken after 30 - $34 \mathrm{~h}$.

9) Samples $S_{7}, S_{8}, S_{9}, S_{10}$ were taken every $20-24 \mathrm{~h}$ at 70, 90, 114 and $138 \mathrm{~h}$ for the long-term investigation.

The fixed stirring rate is to make sure the SPM well mixed and we assume that the total volume of sample $(420 \mathrm{~mL})$ would not affect the results.

\section{Results and Discussion}

\subsection{Phosphorus Content in the Autoclaved and Non-Autoclaved SPM}

Autoclaving is commonly used to sterilise water and sediment/SPM by denaturing the bacteria with high temperatures and pressures [28]. The autoclaving process can however break down the physical structure of particulate matter, increasing the surface to volume ratio [29] so for this work the temperature was kept relatively low $\left(121^{\circ} \mathrm{C}\right)$. Autoclaving will lyse any bacterial cells in the SPM but could also increase the rate of hydrolysis of any organic phosphorus compounds naturally present. However, experiment (Table 1 ) shows that there was no significant difference in the concentration of inorganic or organic $\mathrm{P}$ between the untreated and autoclaved Gunnislake SPM.

The relatively large error bars are due to the heterogeneous nature of the SPM slurry and possibly time differences in the storage period and analysis of different sample. 
Table 1. Phosphorus concentrations in Gunnislake SPM. The concentration values given are the means of three separate samples analysed in triplicate $(n=9)$. Error bars represent \pm 1 s.d.

\begin{tabular}{cccc}
\hline $\begin{array}{c}\text { Phosphorus } \\
\text { species }\end{array}$ & $\begin{array}{c}\text { Gunnislake SPM } \\
\left(\mu \mathrm{g} \cdot \mathrm{g}^{-1}\right)\end{array}$ & $\begin{array}{c}\text { Autoclaved Gunnislake SPM } \\
\left(\mu \mathrm{g} \cdot \mathrm{g}^{-1}\right)\end{array}$ & $\mathrm{t}$-test \\
\hline Inorganic & $820 \pm 36$ & $840 \pm 42$ & $\mathrm{P}=0.82$ \\
Organic & $920 \pm 44$ & $1040 \pm 67$ & $\mathrm{P}=0.19$ \\
Total & $1740 \pm 57$ & $1880 \pm 79$ & $\mathrm{P}=0.27$ \\
\hline
\end{tabular}

\subsection{Phosphorus Equilibration in UHP Water, Biotic River Water and Autoclaved River Water}

The aim of these first experiments was therefore to investigate the release and equilibration of phosphorus species naturally present in the SPM in the presence of different water masses. The results are shown in Figure 1 and the mean concentration changes after $5 \mathrm{~h}$ and $72 \mathrm{~h}$ are given in Table 2. Six batch reactors were set up (duplicate experiments in UHP, biotic and autoclaved Gunnislake river water).

Figure 1(a) and Table 2 show that the releases of DIP and DOP at $5 \mathrm{~h}$ were 33 and $20 \mu \mathrm{g} \cdot \mathrm{L}^{-1}$, respectively, from the SPM to UHP water. Desorption is likely to be the dominant mechanism. The concentration of DIP increased linearly with time over the $5 \mathrm{~h}$ period $\left(\mathrm{R}^{2}=0.986\right.$, slope $\left.=7.02 \mu \mathrm{g} \mathrm{P} \mathrm{L^{-1 }} \mathrm{h}^{-1}\right)$, whereas DOP concentration increased up to $3.5 \mathrm{~h}$ and then gradually decreased. The release of DIP to UHP water continued to increase linearly over the $72 \mathrm{~h}$ period $\left(\mathrm{R}^{2}=\right.$ 0.913 , slope $=1.361 \mu \mathrm{g} \mathrm{L} \mathrm{L}^{-1} \mathrm{~h}^{-1}$ ) with an overall increase of $103 \mu \mathrm{g} \mathrm{P} \mathrm{L} \mathrm{L}^{-1}$ from the start of the experiment (Table 2). The theoretical maximum release of DIP from SPM was $820 \mu \mathrm{g} \mathrm{P} \mathrm{L}^{-1}$ (Table 1); therefore $12.5 \%$ of the total IP pool was released from SPM over $72 \mathrm{~h}$. In contrast the DOP profile showed more temporal variability, with an overall net gain of $56 \mathrm{P} \mathrm{L}^{-1}$ in the water column after $72 \mathrm{~h}$, which is $6 \%$ of the total OP pool in the SPM.

Figure 1(b) shows that in biotic river water DIP and DOP had an inverse relationship over the initial $5 \mathrm{~h}$ period. DIP decreased for the first $2 \mathrm{~h}$ and then increased slightly from $2-5 \mathrm{~h}$; in contrast DOP increased and then decreased over the same time period. However, considering the $5-72 \mathrm{~h}$ period (Figure 1(e)), the DIP concentration remained broadly constant, with no significant net change $\left(-7 \mu \mathrm{g} \mathrm{L} \mathrm{L}^{-1}\right)$. Therefore, although the system is fairly dynamic, the river water matrix appears to inhibit the release of DIP with respect to UHP water. Since the initial DIP concentration in the river water decreases to only $3 \mu \mathrm{g} P$ $\mathrm{L}^{-1}$, this appears to be controlled by the ionic strength of the water matrix. The DOP concentration increased to a steady state water column concentration of 80 $\mu \mathrm{g} \mathrm{P} \mathrm{^{-1 }}$ at $72 \mathrm{~h}$, which is equivalent to $12 \%$ of the total OP pool available from the SPM. The DOP profiles for UHP and river water were similar over the $72 \mathrm{~h}$ timescale, suggesting that the water matrix did not have a significant impact, and showed a net release (UHP: $56 \mu \mathrm{g} \mathrm{P} \mathrm{L}{ }^{-1}$; river water: $58 \mu \mathrm{g} \mathrm{P} \mathrm{L}{ }^{-1}$ ). Desorption from the SPM is the most likely release mechanism after the initial 5 hour 
Table 2. Mean water column DIP/DOP concentrations after $5 \mathrm{~h}$ and $72 \mathrm{~h}$ equilibration. Error bars represent $+/-1$ s.d. of 6 experiments with each sample analysed in triplicate (n $=18$ ) in UHP and Biotic river water; Error bars in abiotic river water experiments represent $+/-1$ s.d. of 4 experiments with each sample analysed in triplicate $(n=12)$.

\begin{tabular}{ccccccc}
\hline Matrix & P species & $\begin{array}{c}\text { Before SPM } \\
\text { addition }\left(\mu \mathrm{g} \mathrm{L}^{-1}\right)\end{array}$ & $\begin{array}{c}5 \mathrm{~h} \text { after SPM } \\
\text { addition }\left(\mu \mathrm{P} \mathrm{L}^{-1}\right)\end{array}$ & $\begin{array}{c}\text { [P] } \\
\text { addition }\left(\mu \mathrm{g} \mathrm{L}^{-1}\right)\end{array}$ & {$[\mathrm{P}]$} \\
\hline \multirow{2}{*}{ UHP } & DIP & 1 & $34 \pm 2$ & +33 & $104 \pm 1$ & +103 \\
& DOP & 1 & $21 \pm 1$ & +20 & $57 \pm 7$ & +56 \\
$\begin{array}{c}\text { Biotic river } \\
\text { water }\end{array}$ & DIP & 49 & $19 \pm 1$ & -30 & $42 \pm 6$ & -7 \\
$\begin{array}{c}\text { Abiotic } \\
\text { river water }\end{array}$ & DOP & 22 & $25 \pm 3$ & +3 & $80 \pm 5$ & +58 \\
\hline
\end{tabular}
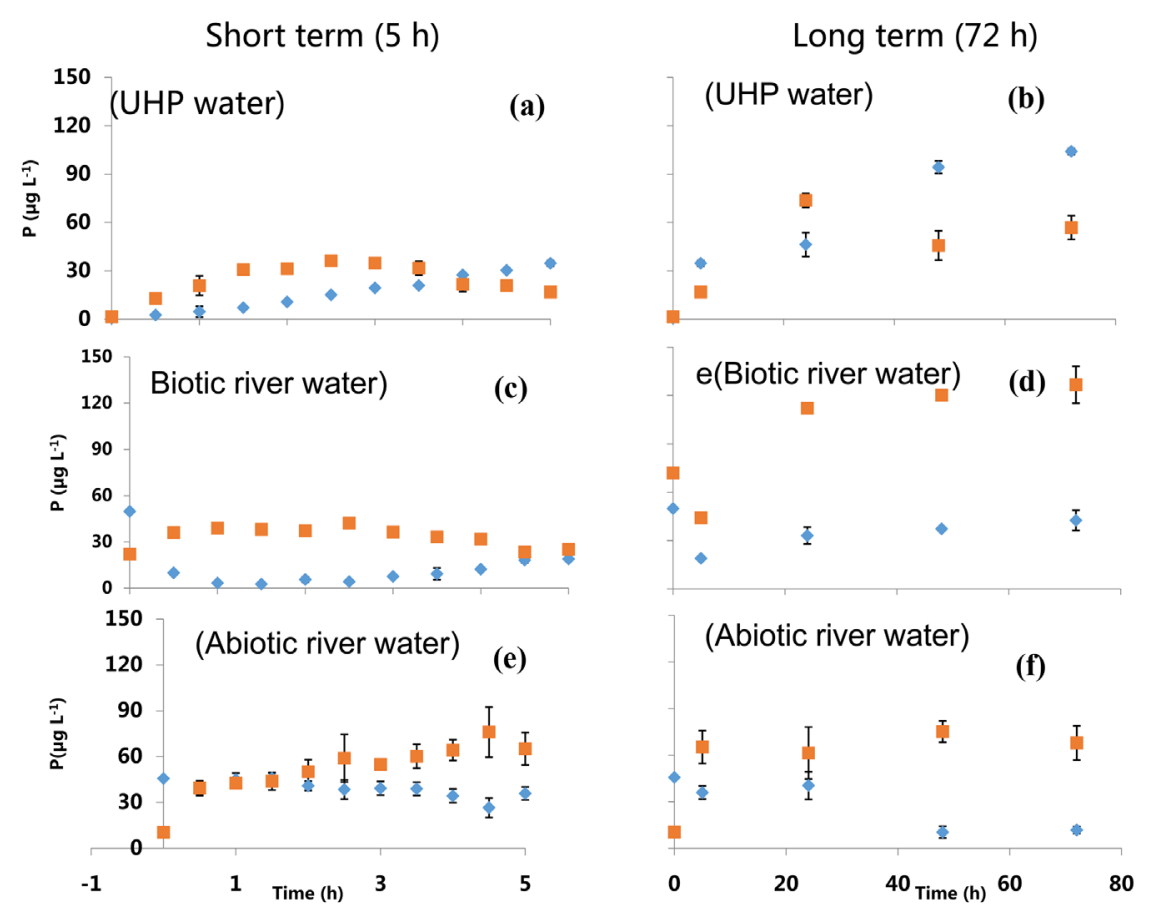

Figure 1. Comparison of P concentrations ( $\downarrow$ DIP; $:=$ DOP) in UHP and Gunnislake river water during short term and long term equilibration experiments. Error bars represent $+/-1$ s.d. of 6 experiments with each sample analysed in triplicate $(n=18)$ in UHP and Biotic river water; Error bars in abiotic river water experiments represent $+/-1$ s.d. of 4 experiments with each sample analysed in triplicate $(n=12)$.

period. The results suggest that the Gunnislake SPM had an initial capacity to take up DIP from the biotic river water, either by bacterial uptake on the SPM surface and/or physical adsorption.

Figure 1(c) shows the changes in the DIP and DOP concentrations during resuspension and equilibration in autoclaved river water. In the first $1.5 \mathrm{~h}$ the DIP concentration did not change significantly but the release of DOP to the water column was more extensive than in the biotic equivalent (from 10 to 43.8 $\mu \mathrm{P} \mathrm{L} \mathrm{L}^{-1}$ ). This may be due to the autoclaving process facilitating OP release, e.g. 
from lysed bacteria [30]. Therefore over the first $5 \mathrm{~h}$ period there was a large increase in DOP $\left(55 \mu \mathrm{g} \mathrm{L} \mathrm{L}^{-1}\right)$ but a relatively small decrease in DIP $\left(9 \mu \mathrm{g} \mathrm{P} \mathrm{L} \mathrm{L}^{-1}\right.$, Table 2). Figure $1(\mathrm{f})$ shows that the DIP concentration gradually decreased further to $12 \mu \mathrm{g} \mathrm{P} \mathrm{L}{ }^{-1}$ at $72 \mathrm{~h}$, with a net loss of $33 \mu \mathrm{g} \mathrm{P} \mathrm{L} \mathrm{L}^{-1}$.

These experiments were intended to be compared to the biotic system to elucidate biological processes; however, autoclaving can sterilize the particle/SPM [31] [32] [33], and thus the autoclaved processes taking place. The physicochemical speciation of iron is particularly important for inorganic phosphorus exchange and this can change during autoclaving [34]. Gunnislake sediment contains $39,500-52,100 \mathrm{mg} \cdot \mathrm{kg}^{-1}$ of iron and sequential extraction of phosphorus from this sediment showed that $465-744 \mu \mathrm{g} \mathrm{P} \mathrm{g}{ }^{-1}$, representing 55\% - 62\% of the TP pool, was bound to iron, making this the dominant P fraction in Gunnislake river sediment [35]. The effects of autoclaving are therefore likely to be an important factor in the contrasting exchange kinetics of DIP in the biotic and autoclaved systems. The DOP concentration remained relatively stable over the $5-72 \mathrm{~h}$ period, which is consistent with the idea of short term release of OP from lysed cells and indicates equilibration between the SPM and the water column, with no enzymatic hydrolysis.

\subsection{Phosphorus Exchange in Spiked UHP Water, Biotic River Water and Autoclaved River Water}

The aim of these experiments was to investigate the effect of adding orthophosphate, G-6-P and phytic acid to an equilibrated SPM-water system, in UHP water and Gunnislake river water. The ability of SPM to adsorb P from the water column is called the SPM phosphorus buffering [36] [37] capacity. The higher the SPM P-buffering capacity, the more P can potentially be absorbed by the SPM [38].

In the UHP water systems, the DIP concentration in the water did not change significantly after spiking with orthophosphate (Figure 2(a)), suggesting rapid adsorption of the orthophosphate. The concentration then stayed constant up to $12 \mathrm{~h}$, and between 12 and $16 \mathrm{~h}$ DIP desorbed to reach its equilibrium concentration of $168 \pm 34 \mu \mathrm{g} \mathrm{P} \mathrm{L}{ }^{-1}$ (Table 3 ). This means that the SPM buffering capacity [36] lasted for $12 \mathrm{~h}$ for DIP, thus an exogenous nutrient input of DIP to a turbulent river (the "ideal" river) would be expected to be buffered for around 12h. The uncertainties associated with the DIP results include the differences between duplicate experiments. The DOP concentration did not change in the UHP water over either time scale, suggesting that there was no DOP/DIP inter-conversion during the experiment.

The SPM buffering capacity was also apparent in biotic river water, but the subsequent release of DIP was much slower than into UHP water, and continued over the entire experiment (192 h; Figure 2(b)). Generally, the DIP concentration in the biotic river water had a linear relationship with time $\left(\mathrm{R}^{2}=0.89\right.$, slope $\left.=0.61 \mu \mathrm{g} \mathrm{P} \mathrm{L} \mathrm{L}^{-1} \mathrm{~h}^{-1}\right)$. The final concentration was comparable to that found in the 


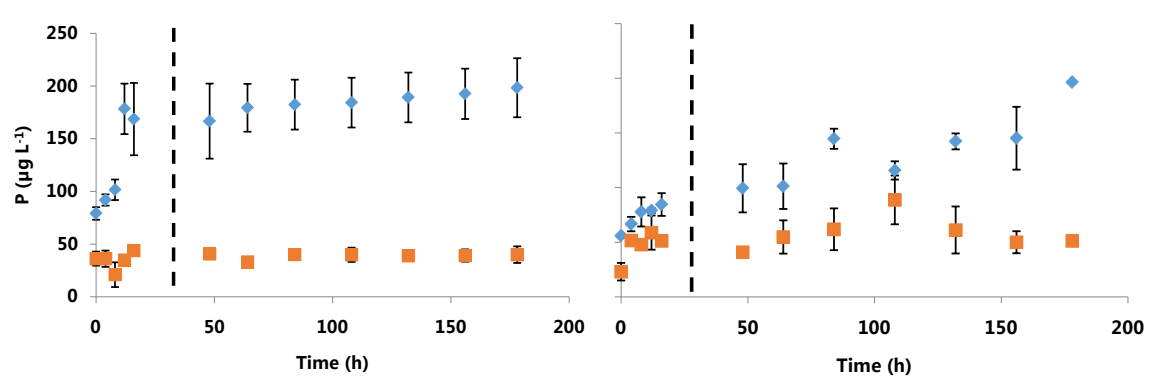

(a)

(b)

Figure 2. Comparison of DIP ( $\downarrow)$ and DOP (•) concentrations during step change experiments spiked with $80 \mu \mathrm{g} \mathrm{P} \mathrm{L}{ }^{-1}$ orthophosphate. Error bars represent 2 experiments and each sample was analysed in triplicate $(n=6)$. (a) UHP water; (b) river water. Time 0 represents the DIP and DOP background concentrations and the time at which the orthophosphate was added. The dashed lines separate the short term and long term time scales.

Table 3. Mean water column $\mathrm{P}$ concentration $16 \mathrm{~h}$ and $190 \mathrm{~h}$ after spiking with $80 \mu \mathrm{g}$ $\mathrm{L}^{-1}$ as orthophosphate.

\begin{tabular}{ccccccc}
\hline Matrix & P species & $\begin{array}{c}\text { Before spiking } \\
\left(\mu \mathrm{g} \mathrm{L} \mathrm{L}^{-1}\right)\end{array}$ & $\begin{array}{c}16 \mathrm{~h}_{\text {after spiking }}\left(\mu \mathrm{g} \mathrm{P} \mathrm{L}^{-1}\right) \\
{[\mathrm{P}]}\end{array}$ & $\begin{array}{c}190 \mathrm{~h}_{\text {after spiking }}\left(\mu \mathrm{g} \mathrm{L} \mathrm{L}^{-1}\right) \\
{[\mathrm{P}]}\end{array}$ \\
\hline UHP & DIP & $79 \pm 6$ & $168 \pm 34$ & +89 & $198 \pm 28$ & +119 \\
& DOP & $36 \pm 6$ & $43 \pm 1$ & +7 & $40 \pm 7$ & +4 \\
$\begin{array}{c}\text { Biotic river } \\
\text { water }\end{array}$ & DIP & $55 \pm 1$ & $99 \pm 10$ & +44 & $196 \pm 1$ & +141 \\
\hline
\end{tabular}

UHP water $\left(198 \mu \mathrm{g} \mathrm{P} \mathrm{L}^{-1}\right)$. Therefore, the SPM buffering capacity in real river systems may be longer-lived than suggested by the UHP water experiments. This indicates that water matrices can positively affect the "P-buffering" capacity of SPM as seen previously by [37]. This is consistent with the higher concentrations of exchangeable $\mathrm{Al}, \mathrm{Fe}$ and organic matter content in river water [38] [39]. The addition of orthophosphate resulted in a rapid release of DOP, which increased from 23 to $51 \mu \mathrm{g} \mathrm{P} \mathrm{L}{ }^{-1}$, presumably due to exchange, but there was no further significant change $(p>0.05)$ over the remaining of the experiment.

G-6-P is quite labile and hence is a potential source of $P$ for bacteria [40] [41]. Figure 3(a), b and c show P exchange between SPM and the water phases after spiking with G-6-P. The DOP concentrations increased after $(4 \mathrm{~h})$ the G-6-P spikes, by $49 \mu \mathrm{g} \mathrm{P} \mathrm{L}^{-1}$ (UHP), $52 \mu \mathrm{g} \mathrm{L} \mathrm{L}^{-1}$ (biotic) and $70 \mu \mathrm{g} \mathrm{P} \mathrm{L}^{-1}$ (autoclaved). Therefore the SPM in UHP and biotic river water had similar buffering capacity for G-6-P of about $30 \mu \mathrm{g} \mathrm{P} \mathrm{L}{ }^{-1}$, whereas in the autoclaved system the buffering capacity was only $10 \mu \mathrm{g} \mathrm{P} \mathrm{L}^{-1}$.

The DOP concentrations generally decreased to $80-100 \mu \mathrm{g} \mathrm{L} \mathrm{L}^{-1}$ (Table 4) during the 4 to $16 \mathrm{~h}$ in all the matrices, as DIP increased, indicating natural hydrolysis of G-6-P after the initial release. Over the longer term, DOP concentrations in UHP and biotic river water remained constant, whereas DOP in autoclaved system continued to decrease to $45 \mu \mathrm{g} \mathrm{P} \mathrm{L}{ }^{-1}$. The DIP concentrations did 
Table 4. Mean water column $\mathrm{P}$ concentration $16 \mathrm{~h}$ and $140 \mathrm{~h}$ after spiking with $80 \mu \mathrm{g}$ $\mathrm{L}^{-1}$ as G-6-P.

\begin{tabular}{ccccccc}
\hline Matrix & P species & $\begin{array}{c}\text { Before spiking } \\
\left(\mu \mathrm{P} \mathrm{L} \mathrm{L}^{-1}\right)\end{array}$ & $\begin{array}{c}16 \mathrm{~h} \text { after spiking } \\
\left(\mu \mathrm{g} \mathrm{P} \mathrm{L}^{-1}\right)\end{array}$ & $16 \mathrm{~h}[\mathrm{P}]$ & $\begin{array}{c}140 \mathrm{~h} \text { after spiking } \\
\left(\mu \mathrm{P} \mathrm{L} \mathrm{L}^{-1}\right)\end{array}$ & $140 \mathrm{~h} \mathrm{[ \textrm {P } ]}$ \\
\hline UHP & DIP & $105 \pm 3$ & $131 \pm 23$ & +26 & $144 \pm 5$ & +39 \\
& DOP & $67 \pm 13$ & $102 \pm 24$ & +35 & $116 \pm 2$ & +49 \\
$\begin{array}{c}\text { Biotic river } \\
\text { water }\end{array}$ & DIP & $128 \pm 18$ & $143 \pm 29$ & +15 & $167 \pm 29$ & +39 \\
$\begin{array}{c}\text { Abiotic river } \\
\text { water }\end{array}$ & DOP & $52 \pm 1$ & $88 \pm 6$ & +36 & $102 \pm 7$ & +50 \\
\hline
\end{tabular}

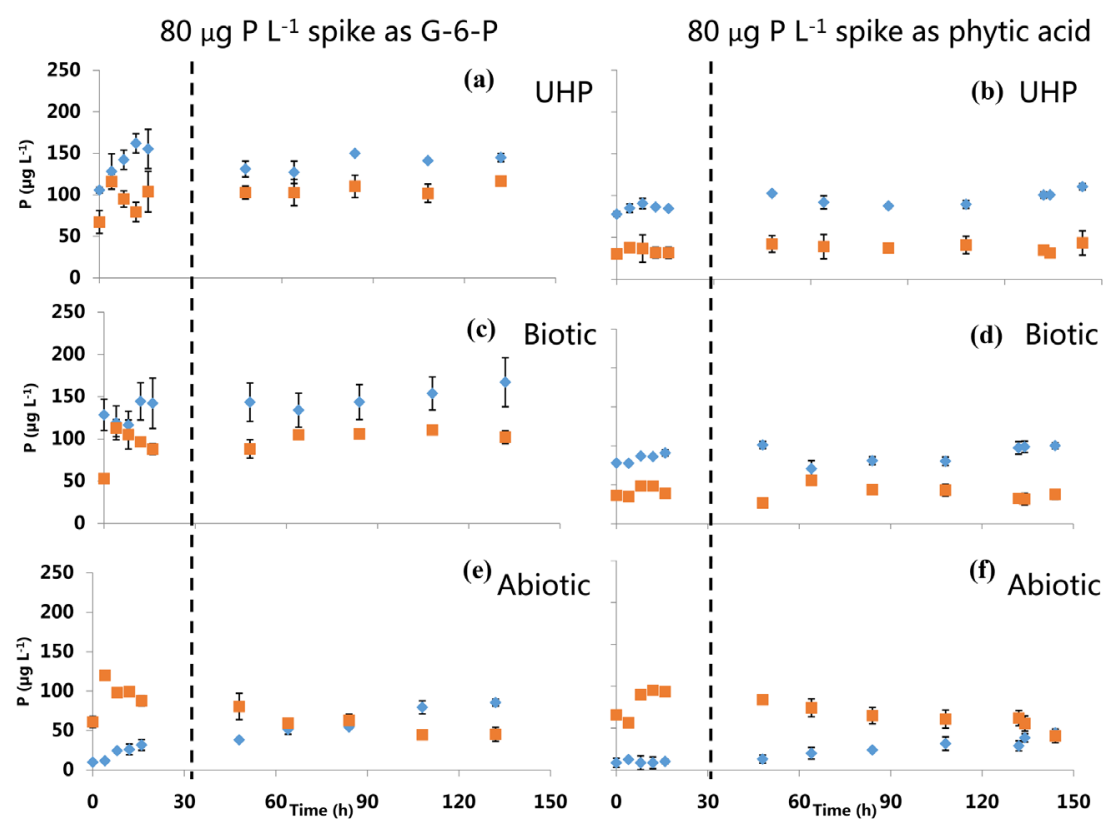

Figure 3. DIP ( $\downarrow)$ and DOP ( $\bullet$ concentration changes during step change experiments with UHP water ( $a$ and d), biotic river water ( $c$ and e) and autoclaved river water ( $c$ and $f$ ) spiked with $80 \mu$ P L L $^{-1}$ G-6-P (a)-(c) and phytic acid (d)-(f). Error bars represent 2 experiments and each sample was analysed in triplicate $(n=6)$. Time 0 represents the DIP and DOP background concentrations and the time at which the G-6-P or phytic acid was added; the dashed lines separate the short term and long term time scales.

not change after $16 \mathrm{~h}$ in the UHP water and biotic river water systems, but increased in the autoclaved system, with overall DOP/DIP $\mathrm{R}^{2}$ of 0.936 . This suggests that hydrolysis is most extensive in the autoclaved system, with all of the added DOP hydrolysed over the course of the experiment.

The SPM also showed a high buffering capacity for phytic acid in the biotic and autoclaved river water systems (Figure 3 ), as the DIP and DOP concentrations did not increase significantly on addition of the spike. In the UHP water systems, a slight initial increase in both DIP and DOP was observed (DIP from 73 - $84 \mu \mathrm{g} \mathrm{P} \mathrm{L}^{-1}$; DOP from 30 - $31 \mu \mathrm{g} \mathrm{P} \mathrm{L}^{-1}$; Table 5 ), but there was no significant $(P=0.77)$ change after this (Figure $3(d))$. These changes in the DOP and 
Table 5. Mean water column $\mathrm{P}$ concentration $16 \mathrm{~h}$ and $190 \mathrm{~h}$ after spiking with $80 \mu \mathrm{g} \mathrm{P}$ $\mathrm{L}^{-1}$ as phytic acid.

\begin{tabular}{ccccccc}
\hline Matrix & P species $\begin{array}{c}\text { Before spiking } \\
\left(\mu \mathrm{g} \mathrm{L} \mathrm{L}^{-1}\right)\end{array}$ & $\begin{array}{c}16 \mathrm{~h} \text { after spiking } \\
\left(\mu \mathrm{g} \mathrm{L}^{-1}\right)\end{array}$ & $16 \mathrm{~h}[\mathrm{P}]$ & $\begin{array}{c}140 \mathrm{~h} \text { after spiking } \\
\left(\mu \mathrm{P} \mathrm{L} \mathrm{L}^{-1}\right)\end{array}$ & $140 \mathrm{~h} \mathrm{[ \textrm {P } ]}$ \\
\hline UHP & DIP & $105 \pm 3$ & $131 \pm 23$ & +26 & $144 \pm 5$ & +39 \\
& DOP & $67 \pm 13$ & $102 \pm 24$ & +35 & $116 \pm 2$ & +49 \\
$\begin{array}{c}\text { Biotic river } \\
\text { water }\end{array}$ & DIP & $128 \pm 18$ & $143 \pm 29$ & +15 & $167 \pm 29$ & +39 \\
$\begin{array}{c}\text { Abiotic } \\
\text { river water }\end{array}$ & DIP & $92 \pm 1$ & $88 \pm 6$ & +36 & $102 \pm 7$ & +50 \\
\hline
\end{tabular}

DIP concentrations indicate that approximately $79 \mu \mathrm{g} \mathrm{P} \mathrm{L}^{-1}$ of phytic acid attached to the SPM and replaced $11 \mu \mathrm{g} \mathrm{P} \mathrm{L}^{-1}$ of DIP.

In the biotic river water experiment, the DIP concentration varied over time, showing a general increase from $77-100 \mu \mathrm{g} \mathrm{L}^{-1}$ and the DOP concentration did not change measurably (Figure $3(\mathrm{e})$ ). In the autoclaved river system, the DOP concentration increased by $29 \mu \mathrm{g} \mathrm{L} \mathrm{L}^{-1}$ over the first $12 \mathrm{~h}$, and there was no significant DIP release (Figure $3(\mathrm{f})$ ) over the same time scale. The longer term profile (16 - $150 \mathrm{~h})$ showed a "mirror-image" relationship with DOP decreasing and DIP increasing (DOP/DIP, $\mathrm{R}^{2}=0.693$ ). Considering the experimental conditions and the refractory nature of phytic acid, the physical exchange of phytic acid with orthophosphate at the SPM surface should be the only possible process in this experiment. Therefore, since the initial sorption of phytic acid did not displace IP, it appears that the slower second phase of sorption involves a different process from the initial buffering.

\section{Conclusions}

In these constantly stirred batch reactor experiments, the water matrix had a significant effect on the release of IP and OP during equilibration with SPM and on the buffering capacity of the SPM when the systems were spiked with orthophosphate. SPM exhibited a greater DIP buffering capacity in the river water matrix compared with UHP water during equilibration. Following addition of $\mathrm{P}$ species to the equilibrated system, the SPM was able to buffer all of the orthophosphate and phytic acid added to both UHP and river water. However, the initial SPM buffering capacity was much lower for G-6-P. However hydrolysis of the G-6-P occurred within the first $16 \mathrm{~h}$ in the UHP (56\%) and biotic river water (55\%) experiments, and effectively all of the G-6-P added was hydrolysed in the autoclaved experiments over $140 \mathrm{~h}$. The buffering capacity of the SPM for phytic acid was high (95\% - 98\% removed) and permanent in UHP and biotic river water, whereas phytic acid was cycled in the autoclaved experiments.

The results in this paper suggest that in a turbulent river, DIP and DOP will reach equilibrium between the particulate matter and the water column within $24 \mathrm{~h}$. If there is an exogenous nutrient input of DIP to the river, the initial buf- 
fering capacity of the SPM will be effective for $12-16 \mathrm{~h}$. If there is an input of DOP, the SPM will have a high and permanent buffering capacity for refractory species such as phytic acid, but a much lower buffering capacity for labile species such as G-6-P. The water matrix will however have limited influence on the exchange of added DOP between SPM and water. Any input of labile DOP to a river will undergo hydrolysis and release DIP over short timescales. Any input of refractory DOP however will not be hydrolysed but will be involved in P cycling through displacement of DIP from the surface of particulate matter. Finally, the Gunnislake River clearly cannot represent the "ideal" river, therefore P dynamics with different environmental conditions requires further studies for the next step.

\section{Acknowledgements}

This project is financially supported by The National Key Research and Development Program of China (2017YFA0604903) and the National Natural Science Foundation of China (41571510).

\section{References}

[1] Shainee, M., Leira, B.J., Ellingsen, H. and Fredheim, A. (2014) Investigation of a Self-Submersible SPM Cage System in Random Waves. Aquacultural Engineering, 58, 35-44. https://doi.org/10.1016/j.aquaeng.2013.10.003

[2] Fettweis, M., Francken, F., Van den Eynde, D., Verwaest, T., Janssens, J. and Van Lancker, V. (2010) Storm Influence on SPM Concentrations in a Coastal Turbidity Maximum Area with High Anthropogenic Impact (Southern North Sea). Continental Shelf Research, 30, 1417-1427. https://doi.org/10.1016/j.csr.2010.05.001

[3] Wainright, S.C. (1990) Sediment-to-Water Fluxes of Particulate Material and Microbes by Resuspension and Their Contribution to the Planktonic Food Web. Marine Ecology Progress Series, 62, 271-281. https://doi.org/10.3354/meps062271

[4] Wan Jun, W.Z. and Qian, S.-Q. (2011) Distribution of Bioavailable Phosphorus between Over-Lying Water and SPM under Abrupt Expansion Condition. Journal of Hydrodynamics, 23, 398-406. https://doi.org/10.1016/S1001-6058(10)60129-1

[5] Wei, X. and Lu, S.-Y. (2014) Effects of Inactivation Agents and Temperature on Phosphorus Release from Sediment in Dianchi Lake, China. Environmental Earth Sciences, 74, 3857-3865. https://doi.org/10.1007/s12665-014-3910-5

[6] Wang, J., Chen, J., Ding, S., Luo, J. and Xu, Y. (2015) Effects of Temperature on Phosphorus Release in Sediments of Hongfeng Lake, Southwest China: An Experimental Study Using Diffusive Gradients in Thin-Films (DGT) Technique. Environmental Earth Sciences, 74, 5885-5894. https://doi.org/10.1007/s12665-015-4612-3

[7] Jiang, X., Jin, X., Yao, Y., Li, L. and Wu, F. (2008) Effects of Biological Activity, Light, Temperature and Oxygen on Phosphorus Release Processes at the Sediment and Water Interface of Taihu Lake, China. Water Research, 42, 2251-2559. https://doi.org/10.1016/j.watres.2007.12.003

[8] Xu, Y., Hu, H., Liu, J., Luo, J., Qian, G. and Wang, A. (2015) pH Dependent Phosphorus Release from Waste Activated Sludge: Contributions of Phosphorus Speciation. Chemical Engineering Journal, 267, 260-265.

https://doi.org/10.1016/j.cej.2015.01.037 
[9] Latif, M.A., Mehta, C.M. and Batstone, D.J. (2015) Low pH Anaerobic Digestion of Waste Activated Sludge for Enhanced Phosphorous Release. Water Research, 81, 288-293. https://doi.org/10.1016/j.watres.2015.05.062

[10] Wu, Y., Wen, Y., Zhou, J. and Wu, Y. (2013) Phosphorus Release from Lake Sediments: Effects of $\mathrm{pH}$, Temperature and Dissolved Oxygen. KSCE Journal of Civil Engineering, 18, 323-329. https://doi.org/10.1007/s12205-014-0192-0

[11] Katsev, S. and Dittrich, M. (2013) Modeling of Decadal Scale Phosphorus Retention in Lake Sediment under Varying Redox Conditions. Ecological Modelling, 251, 246-259. https://doi.org/10.1016/j.ecolmodel.2012.12.008

[12] Steenbergh, A.K., Bodelier, P.L.E., Slomp, C.P. and Laanbroek, H.J. (2014) Effect of Redox Conditions on Bacterial Community Structure in Baltic Sea Sediments with Contrasting Phosphorus Fluxes. PLoS ONE, 9, e92401.

https://doi.org/10.1371/journal.pone.0092401

[13] He, Z., Griffin, T.S. and Honeycutt, C.W. (2004) Enzymatic Hydrolysis of Organic Phosphorus in Swine Manure and Soil Trade or Manufacturers' Names Mentioned in the Paper Are for Information Only and Do Not Constitute Endorsement, Recommendation, or Exclusion by the USDA-ARS. Journal of Environmental Quality, 33, 367-372.

[14] Lehtola, M.J., Miettinen, I.T., Vartiainen, T., Myllykangas, T. and Martikainen, P.J. (2001) Microbially Available Organic Carbon, Phosphorus, and Microbial Growth in Ozonated Drinking Water. Water Research, 35, 1635-1640. https://doi.org/10.1016/S0043-1354(00)00449-8

[15] Holtan, H., Kamp-Nielsen, L. and Stuanes, A.O. (1988) Phosphorus in Soil, Water and Sediment: An Overview. Hydrobiologia, 170, 19-34. https://doi.org/10.1007/BF00024896

[16] Charpy-Roubaud, C., Charpy, L. and Sarazin, G. (1996) Diffusional Nutrient Fluxes at the Sediment-Water Interface and Organic Matter Mineralization in an Atoll Lagoon (Tikehau, Tuamotu Archipelago, French Polynesia). Marine Ecology Progress Series, 132, 181-190. https://doi.org/10.3354/meps132181

[17] Stutter, M.I., Langan, S.J. and Cooper, R.J. (2008) Spatial Contributions of Diffuse Inputs and Within-Channel Processes to the Form of Stream Water Phosphorus over Storm Events. Journal of Hydrology, 350, 203-214.

https://doi.org/10.1016/j.jhydrol.2007.10.045

[18] Gardolinski, P.C.F.C., Worsfold, P.J. and McKelvie, I.D. (2004) Seawater Induced Release and Transformation of Organic and Inorganic Phosphorus from River Sediments. Water Research, 38, 688-692. https://doi.org/10.1016/j.watres.2003.10.048

[19] Dallas, L.J. and Jha, A.N. (2015) Applications of Biological Tools or Biomarkers in Aquatic Biota: A Case Study of the Tamar Estuary, South West England. Marine Pollution Bulletin, 95, 618-633. https://doi.org/10.1016/j.marpolbul.2015.03.014

[20] Ussher, S.J., Manning, A.J., Tappin, A.D. and Fitzsimons, M.F. (2011) Observed Dissolved and Particulate Nitrogen Concentrations in a Mini Flume. Hydrobiologia, 672, 69-77. https://doi.org/10.1007/s10750-011-0759-4

[21] Sheehan, M.R. and Ellison, J.C. (2014) Intertidal Morphology Change Following Spartina anglica Introduction, Tamar Estuary, Tasmania. Estuarine, Coastal and Shelf Science, 149, 24-37. https://doi.org/10.1016/j.ecss.2014.07.006

[22] Sadri, S.S. and Thompson, R.C. (2014) On the Quantity and Composition of Floating Plastic Debris Entering and Leaving the Tamar Estuary, Southwest England. Marine Pollution Bulletin, 81, 55-60.

https://doi.org/10.1016/j.marpolbul.2014.02.020 
[23] Dallas, L.J., Cheung, V.V., Fisher, A.S. and Jha, A.N. (2012) Relative Sensitivity of Two Marine Bivalves for Detection of Genotoxic and Cytotoxic Effects: A Field Assessment in the Tamar Estuary, South West England. Environmental Monitoring and Assessment, 185, 3397-3412. https://doi.org/10.1007/s10661-012-2800-0

[24] Uncles, R.J. and Mitchell, S.B. (2011) Turbidity in the Thames Estuary: How Turbid Do We Expect It to Be? Hydrobiologia, 672, 91-103. https://doi.org/10.1007/s10750-011-0757-6

[25] Costas, M., Prego, R., Filgueiras, A.V. and Bendicho, C. (2011) Land-Ocean Contributions of Arsenic through a River-Estuary-Ria System (SW Europe) under the Influence of Arsenopyrite Deposits in the Fluvial Basin. Science of the Total Environment, 412-413, 304-314. https://doi.org/10.1016/j.scitotenv.2011.10.034

[26] Miller, A.E.J. (1999) Seasonal Investigations of Dissolved Organic Carbon Dynamics in the Tamar Estuary, U.K. Estuarine, Coastal and Shelf Science, 49, 891-908. https://doi.org/10.1006/ecss.1999.0552

[27] Zhao, J. and Liu, X. (2013) Organic and Inorganic Phosphorus Uptake by Bacteria in a Plug-Flow Microcosm. Frontiers of Environmental Science \& Engineering, 7, 173-184. https://doi.org/10.1007/s11783-013-0494-3

[28] Aminot, A. and Kérouel, R. (1995) Reference Material for Nutrients in Seawater: Stability of Nitrate, Nitrite, Ammonia and Phosphate in Autoclaved Samples. Marine Chemistry, 49, 221-232. https://doi.org/10.1016/0304-4203(95)00004-B

[29] Kleeberg, A. and Grüneberg, B. (2005) Phosphorus Mobility in Sediments of Acid Mining Lakes, Lusatia, Germany. Ecological Engineering, 24, 89-100. https://doi.org/10.1016/j.ecoleng.2004.12.010

[30] Serrasolses, I., Romanya, J. and Khanna, P.K. (2008) Effects of Heating and Autoclaving on Sorption and Desorption of Phosphorus in Some Forest Soils. Biology and Fertility of Soils, 44, 1063-1072. https://doi.org/10.1007/s00374-008-0301-7

[31] Anderson, B.H. and Magdoff, F.R. (2005) Autoclaving Soil Samples Affects Algal-Available Phosphorus. Journal of Environmental Quality, 34, 1958-1963. https://doi.org/10.2134/jeq2005.0024

[32] Carter, D.O., Yellowlees, D. and Tibbett, M. (2007) Autoclaving Kills Soil Microbes Yet Soil Enzymes Remain Active. Pedobiologia, 51, 295-299. https://doi.org/10.1016/j.pedobi.2007.05.002

[33] Choi, W.S., Rodríguez, R.A. and Sobsey, M.D. (2014) Persistence of Viral Genomes after Autoclaving. Journal of Virological Methods, 198, 37-40. https://doi.org/10.1016/j.jviromet.2013.12.021

[34] Dundar, A.N. and Gocmen, D. (2013) Effects of Autoclaving Temperature and Storing Time on Resistant Starch Formation and Its Functional and Physicochemical Properties. Carbohydrate Polymers, 97, 764-771. https://doi.org/10.1016/j.carbpol.2013.04.083

[35] Monbet, P., McKelvie, I.D. and Worsfold, P.J. (2009) Dissolved Organic Phosphorus Speciation in the Waters of the Tamar Estuary (SW England). Geochimica et Cosmochimica Acta, 73, 1027-1038. https://doi.org/10.1016/j.gca.2008.11.024

[36] Carritt, D.E. and Goodgal, S. (1954) Sorption Reactions and Some Ecological Implications. Deep Sea Research, 1, 224-243.

[37] García-Luque, E., Forja Pajares, J.M. and Gómez-Parra, A. (2006) Assessing the Geochemical Reactivity of Inorganic Phosphorus along Estuaries by Means of Laboratory Simulation Experiments. Hydrological Processes, 20, 3555-3566. https://doi.org/10.1002/hyp.6145 
[38] Kleeberg, A., Schapp, A. and Biemelt, D. (2008) Phosphorus and Iron Erosion from Non-Vegetated Sites in a Post-Mining Landscape, Lusatia, Germany: Impact on Aborning Mining Lakes. Catena, 72, 315-324. https://doi.org/10.1016/j.catena.2007.06.002

[39] Froelich, P.N. (1988) Kinetic Control of Dissolved Phosphate in Natural Rivers and Estuaries: A Primer on the Phosphate Buffer Mechanism. Limnology and Oceanography, 33, 649-669. https://doi.org/10.4319/lo.1988.33.4_part_2.0649

[40] Turner, B.L., McKelvie, I.D. and Haygarth, P.M. (2002) Characterisation of Water-Extractable Soil Organic Phosphorus by Phosphatase Hydrolysis. Soil Biology and Biochemistry, 34, 27-35. https://doi.org/10.1016/S0038-0717(01)00144-4

[41] Kirkman, H.N. and Gaetani, G.F. (1986) Regulation of Glucose-6-Phosphate Dehydrogenase in Human Erythrocytes. Journal of Biological Chemistry, 261, 4033-4038. 